\title{
USING CANINE TEETH FOR SEX DETERMINATION OF THE SOUTH AMERICAN FUR SEAL, ARCTOCEPHALUS AUSTRALIS
}

\author{
D.Molina-Schiller ${ }^{1,2}$ and M.C.Pinedo ${ }^{2}$
}

\begin{abstract}
Upper and lower canine teeth of 221 Arctocephalus australis (104 males, 66 females and 51 unknown sex) were extracted from dead animals stranded on the Rio Grande do Sul coast from 1977 to 1997. These teeth were measured and used as a tool in sex estimation. Measurements of the angle of the crown on canine teeth (method 1) and measurements of the crown and root on canines (method 2) were compared with the purpose of evaluating which method is more reliable in sex estimation. Stepwise discriminant analysis showed that method 2 was the most reliable. Discriminant functions for upper and lower canines were obtained for males and females where sex was known. Discriminant functions were also obtained for all canines according to the physical maturity of skull (physically immature and physically mature).

Resumen - Dientes caninos superiores e inferiores de 221 Arctocephalus australis (104 machos, 66 hembras y 51 sexo desconocido) fueron extraídos de animales encontrados muertos en la costa de Rio Grande do Sul desde 1977 a 1997 . Estos dientes fueron medidos y usados como herramienta en estimación del sexo. Medidas del ángulo de la corona en dientes caninos (método 1) y medidas de la corona y raíz en los caninos (método 2) fueron comparados con el propósito de evaluar cual de esos métodos es más confiable en la estimación del sexo. Análisis discriminante stepwise mostraron que el método 2 fue más confiable. Funciones discriminantes para caninos superiores e inferiores fueron obtenidas para machos y hembras de sexo conocido. Funciones discriminantes también fueron obtenidas para todos los caninos según la madurez física de cráneo (físicamente inmaduro y físicamente maduro).
\end{abstract}

Keywords: Arctocephalus australis, South American fur seal, canines, teeth sex determination, sexual dimorphism, Southern Brazil.

\section{Introduction}

Sexual dimorphism has been reported for several species of pinnipeds (e.g. Scheffer, 1958; Ridgway and Harrison, 1981; King, 1983; Crespo 1984; Riedman, 1990; Laws, 1993; Le Boeuf and Laws, 1994; Brunner, 2002).

Sex determination can be difficult if not impossible in decomposed animals. Furthermore, if the osteological material of interest is from physically immature individuals, sexual dimorphism is less evident.

To overcome these problems in pinnipeds two methods have been used in sex determination using canine teeth. Crespo (1984) measured the angle of the crown of canine teeth of 78 South American sea lion, Otaria flavescens (40 individuals of known sex and 38 individuals of unknown sex). He found that the angle of the crown conditioned the future diameter of the tooth. Lowry and Folk (1990) determined the sex of 111 individuals (68 males and 43 females) of Zalophus californianus by measuring the crown and root (length, width and thickness) of each upper and lower canine tooth. They considered that the size of the crown of the tooth remains constant throughout life.

In Rio Grande do Sul, considering that sex determination was not possible in $23 \%$ of $A$. australis stranded and that most specimens were physically immature (MolinaSchiller, 2000), canine teeth were used as a tool in the sex determination. Therefore the objective of this work was to apply and compare in A. australis two known methods for sex determination in pinnipeds, and evaluate their reliability for this species.

\section{Material and Methods}

Study area and analyse

Canine teeth upper and lower of 221 A. australis (104 males, 66 females and 51 specimens of unknown sex) were collected and examined, from dead animals found along the coast of Rio Grande do Sul, $\left(29^{\circ} 20^{\prime} \mathrm{S}, 49^{\circ} 44^{\prime} \mathrm{W}\right.$ to $\left.33^{\circ} 45^{\prime} \mathrm{S}, 53^{\circ} 22^{\prime} \mathrm{W}\right)$ from July 1977 to September 1997. The coast has been surveyed as part of a long-term beach monitoring program conducted by the Laboratory of Marine Mammals and Marine Turtles (LMM) of the Oceanography Department of the Fundação Universidade Federal do Rio Grande (FURG), Brazil. The osteological material collected was accessed at LMM.

Statistical methods of ANOVA/MANOVA analysis were made using Program Statistics 5.0 for Windows. The stepwise discriminant analysis procedure was used for individuals of known sex. Discriminant functions were used to separate the canine teeth according to the known sex and physical development of the skull. This classification was performed according to the age of attainment of the physical maturity of the skull, previously observed in growth curve analyses to be 8 years in the males and 6 years in females (Molina-Schiller, 2000). Ages were also previously estimated from upper canine decalcified on-center cuts by counting the growth layers groups (GLGs) in the dentine and cementum (Molina-Schiller, 2000).

For the selection of the most reliable method for sex estimation of canine teeth of $A$. australis, the method with the highest percentage of success was selected. The discriminant functions obtained were applied to the individuals of unknown sex.

\footnotetext{
${ }^{1}$ Current address: Universidade Federal do Rio Grande do Sul, Pós-Graduação em Ecologia. Avenida Bento Gonçalves, 9500. Caixa Postal 15007, Porto Alegre, RS 91540-000 Brazil. E-mail: daniza@marinemammals.cl

${ }^{2}$ Fundação Universidade Federal do Rio Grande (FURG), Departamento de Oceanografia. Caixa Postal 474, Rio Grande, RS 96201-900 Brazil.
} 
Angle measurements of the crown (Method 1)

The crowns of upper and lower canines of A. australis are curved although in lower canines this curvature is more pronounced. Therefore it was considered necessary to modify the methodology used by Crespo (1984) due to the degree of curvature observed and only the upper canines were measured. Two measures were taken with a protractor: A) angle from the apex of the crown to the first-third of the crown (ANGR) and B) maximum angle of the crown (ANGA), considering only the straight portion without curvature (Figure 1). To avoid errors in the measurements, canines with wear on the apex of the crown were not included in the analysis.
Axis measurements of the crown and root (Method 2)

All upper and lower canines were measured along five axes according to (Lowry and Folk 1990) with $0.01 \mathrm{~mm}$ precision. The measurements were: A) crown length (CL), B) maximum crown width (CW), C) maximum root width (RW), D) crown thickness (CT) and E) root thickness (RT). Canine length also was introduced (F) for both upper (UCL) and lower (LCL) canines (Figure 2). Measurements A, B and C were taken with the tooth at a lateral position and measurements $D$ and $E$ with the tooth at an anterior position. Again to avoid measurement errors crowns with wearing apex were not included in the analysis. Differences in dental position (upper, lower right and left) were also tested using Student t-test analysis (Zar, 1984).
A

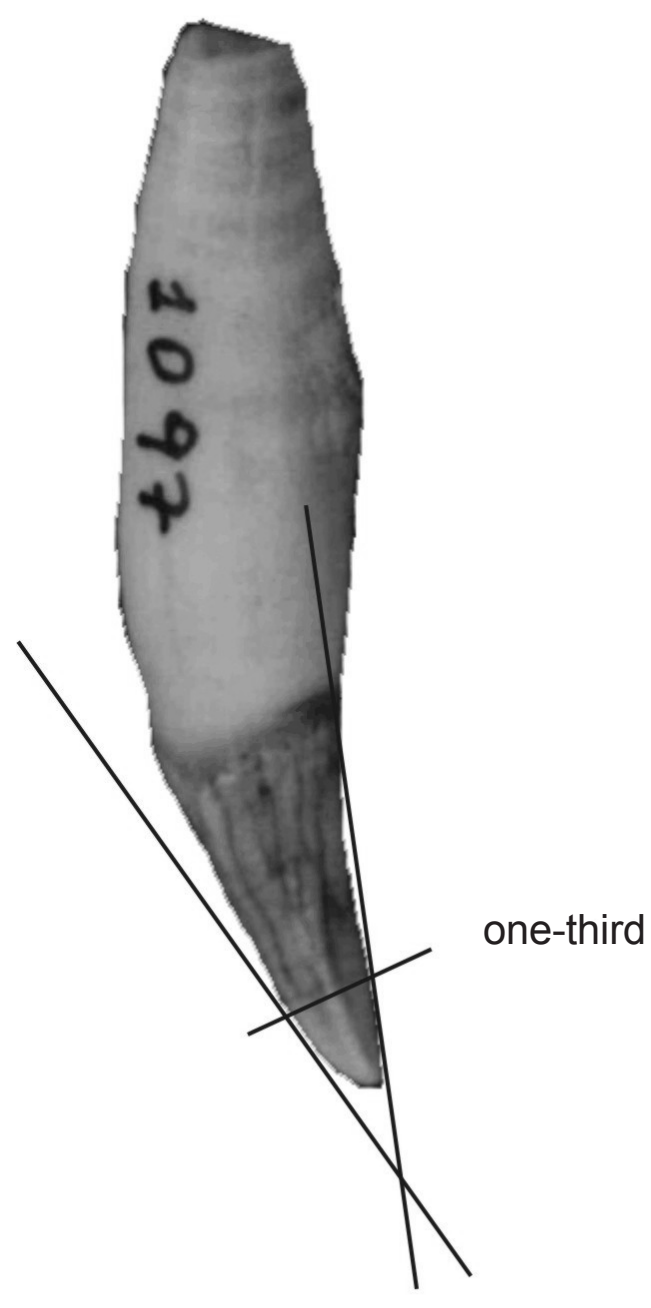

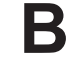

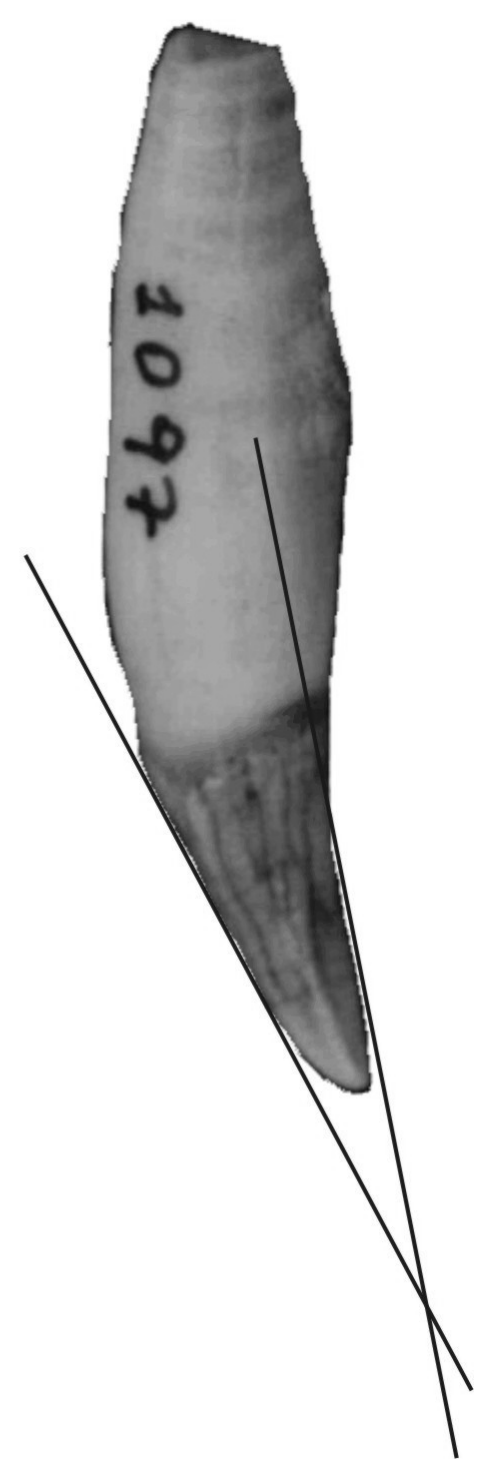

Figure 1. Angle measurements of the crown in the canine teeth of A. australis: (A) angle from the apex of the crown to the first-third of the crown (ANGR) and (B) maximum angle of the crown (ANGA), considering only the straight portion without curvature. 

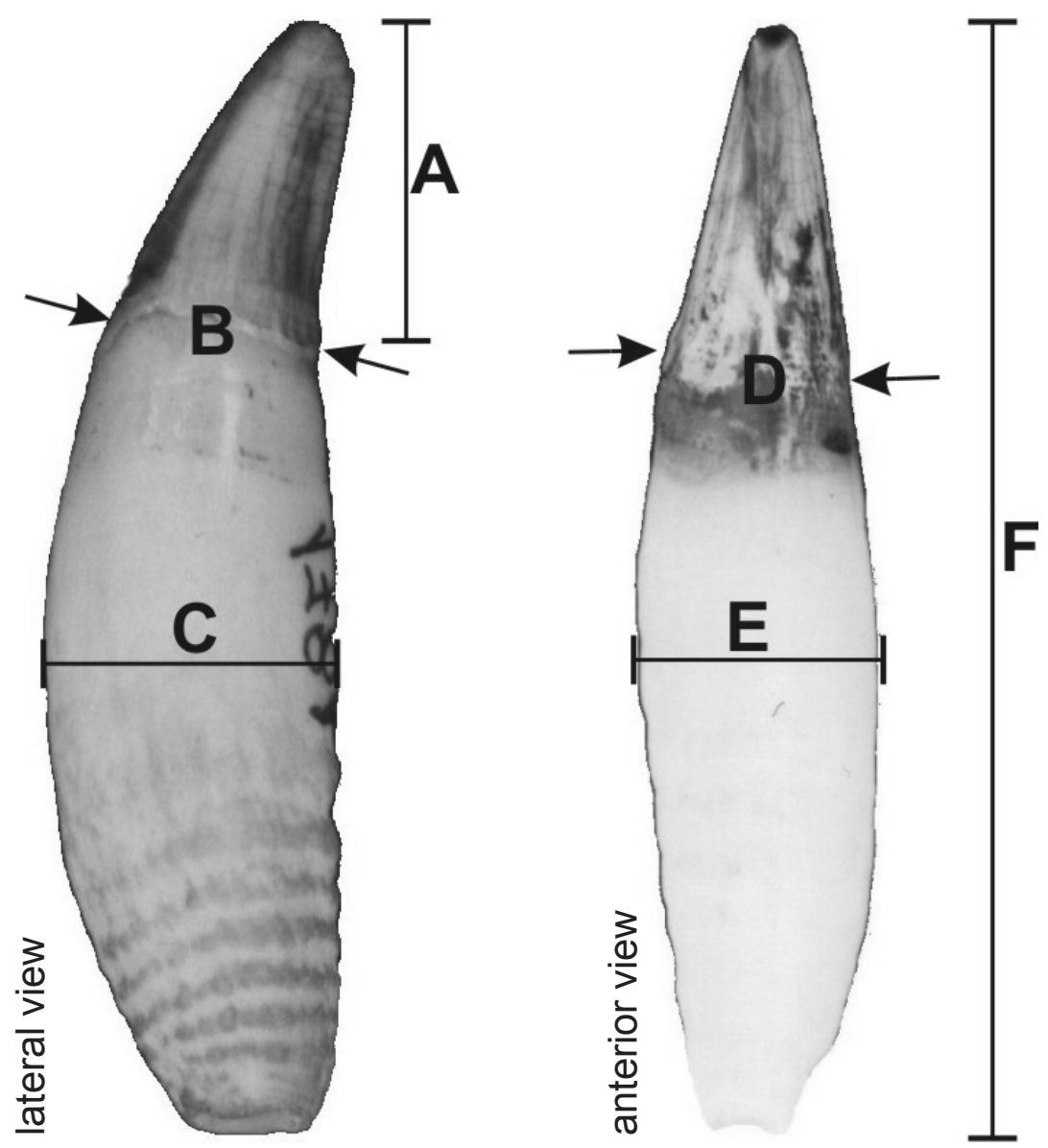

Figure 2. Axe measurements of the crown and root of upper canine teeth of A. australis: (A) crown length, (B) maximum crown width, (C) maximum root width, (D) crown thickness, (E) root thickness and (F) canine length.

\section{Results}

Method 1 - Angle measurements of the crown

In all canines, the angles of physically immature and physically mature individuals were higher for males than females (Table 1). The discriminant analysis classified the two variables as dimorphic: maximum angle of the crown (ANGA) and angle from the apex of the crown to the firstthird of the crown (ANGR) (Wilks' Lambda=0.50246; $\mathrm{F}(2.167)=82.682 ; \mathrm{p}<0.0001)$. The discriminant function $(n=170)$ presented $87.7 \%$ success in the classification of sex. Twenty-one individuals were erroneously classified (11 males and 10 females). The functions for measurements of the angle of the crown by sex derived for upper canines were:

$$
\begin{aligned}
& O^{*}=-155.836+4.216 \text { (ANGA) + } 14.237 \text { (ANGR) } \\
& \text { 우 }=-126.584+3.134 \text { (ANGA) + } 13.588 \text { (ANGR) }
\end{aligned}
$$

In order to determine sex, the measured angle is replaced in both equations. The sex attributed will correspond to the one with the highest value in the discriminant function. The results of the Student t-test analysis of canine teeth angles of physically mature and physically immature individuals showed some difference $(\mathrm{p}<0.001)$. In both development classes the angles of the crown of the canine tooth in males were larger than in female canines (Table 1).

\section{- Physically immatures}

The discriminant functions of measurements of the angle of the crown by sex derived for upper canines of physically immature individuals ( 80 males and 48 females) were $87.5 \%$ accurate (Wilks' Lambda $=0.52563 ; \mathrm{F}(2.125)=56.404$; $\mathrm{p}<0.0000$ ) and sixteen individuals were erroneously classified ( 5 males and 11 females). The functions for upper canines were:

ठ' $=-138.825+4.412($ ANGA $)+11.898$ (ANGR)

오 $=-112.278+3.372($ ANGA $)+11.369$ (ANGR)

- Physically matures

The discriminant functions of measurements of the angle of the crown by sex derived for upper canines of physically mature individuals (19 males and 12 females) were $96.8 \%$ accurate (Wilks' Lambda $=0.52563 ; \mathrm{F}(2.125)=56.404$; $\mathrm{p}<0.0000)$. Only one male was erroneously classified. These functions were:

б" $=-512.722+2.033($ ANGA $)+60.848$ (ANGR)

오 $=-406.692+0.980($ ANGA $)+55.156($ ANGR $)$ 
Table 1. Student t-test analysis of angle of the crown of canines (method 1) of A. australis of known sex.

\begin{tabular}{|c|c|c|c|c|c|c|c|c|c|c|c|c|c|c|}
\hline $\begin{array}{l}\text { PHYSICAL } \\
\text { DEVELOPMENT }\end{array}$ & & & & & & & SEX & & & & & & & \\
\hline \multirow{4}{*}{ Immatures } & & & & 오 & & & & & o & & & & & \\
\hline & & $\mathrm{n}$ & mean & SD & $\min$ & $\max$ & $\mathrm{n}$ & mean & SD & $\min$ & $\max$ & $\mathrm{t}$ & d.f. & $\mathrm{p}$ \\
\hline & ANGA & 60 & 16.55 & 1.13 & 15 & 22 & 83 & 19.89 & 1.62 & 16 & 24 & -13.73 & 141 & $<0.0001$ \\
\hline & ANGR & 60 & 14.48 & 0.62 & 13 & 19 & 83 & 16.00 & 1.29 & 14 & 19 & -8.43 & 141 & $<0.0001$ \\
\hline \multirow{4}{*}{ Matures } & 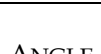 & & & 우 & & & & & $\sigma^{\prime}$ & & & & & \\
\hline & & $\mathrm{n}$ & mean & SD & $\min$ & $\max$ & $\mathrm{n}$ & mean & SD & $\min$ & $\max$ & $\mathrm{t}$ & d.f. & $\mathrm{p}$ \\
\hline & ANGA & 15 & 16.67 & 1.23 & 15 & 18 & 23 & 20.22 & 1.48 & 19 & 24 & -7.71 & 36 & $<0.0001$ \\
\hline & ANGR & 15 & 14.33 & 0.49 & 14 & 15 & 23 & 16.26 & 0.62 & 15 & 17 & -10.16 & 36 & $<0.0001$ \\
\hline
\end{tabular}

(ANGA) maximum angle of the crown, (ANGR) angle from the apex of the crown to the one-third of the crown, (min) minimum, (max) maximum

\section{Method 2- Axis measurements of the crown and root}

The Student t-test analysis of the canines according to the dental position (upper, lower) showed differences $(p<0.05)$. However no differences were found between right or left canines ( $p>0.05)$. Therefore, left superior and inferior canines were preferably used.

The analysis statistics showed that in all measurements males presented equal or higher values than females (Table 2).

- Upper canines of physically immature and physically mature individuals

The discriminant analysis classified upper canine measurements as dimorphic for maximum root width (RW), and crown length (CL) (Wilks' Lambda=0.40103; $\mathrm{F}(2.158)=117.99 ; \mathrm{p}<0.0001)$. The discriminant functions $(n=161)$ were $91 \%$ successful in the classification of sex. Fifteen individuals were erroneously classified ( 9 males and 6 females). The functions of measurements of crown and root by sex derived for upper canines were:

$\mathrm{O}^{\prime \prime}=-58.236+1.787(\mathrm{RW})+5.503(\mathrm{CL})$

우 $=-36.738+0.689(\mathrm{RW})+4.831(\mathrm{CL})$

- Lower canines of physically immature and physically mature individuals

The discriminant analysis classified two variables as dimorphic for lower canines measurements as for maximum crown width (CW) and root thickness (RT) (Wilks' Lambda $=0.52445 ; \mathrm{F}(2.99)=44.885 ; \mathrm{p}<0.0001)$. The discriminant functions $(n=102)$ were $87 \%$ successful in the classification of sex. Thirteen individuals were erroneously classified (8 males and 5 females).The functions of measurements of the crown and root by sex derived for lower canines were:

б $=-20.514+3.384(\mathrm{CW})+0.438(\mathrm{RT})$

우 $=-10.295+2.435(\mathrm{CW})+0.199(\mathrm{RT})$

\section{- Upper canines of physically immatures}

The discriminant analysis classified maximum root width (RW) and crown thickness (CT) as dimorphic variables for upper canines of physically immature individuals (Wilks' Lambda $=0.45020 ; \mathrm{F}(2.121)=73.885$; $\mathrm{p}<0.0001)$. The discriminant functions $(\mathrm{n}=124)$ were $90.32 \%$ successful in the classification of sex. Twelve individuals were erroneously classified (4 males and 8 females). The functions of measurements of the crown and root by sex derived for upper canines were:

$\sigma^{\prime \prime}=-34.400+2.146(\mathrm{RW})+4.648(\mathrm{CT})$

우 $=-19.161+1.243(\mathrm{RW})+3.822(\mathrm{CT})$

\section{- Lower canines of physically immatures}

The discriminant analysis classified the same variables as above (RW and CT) as dimorphic for lower canines of physically immature individuals (Wilks' Lambda $=0.57935 ; \mathrm{F}(2.176)=27.591 ; \mathrm{p}<0.0001)$. The discriminant functions $(\mathrm{n}=179)$ were $87.34 \%$ successful in the classification of sex. Ten individuals were erroneously classified ( 3 males and 7 females). The functions of measurements of the crown and root by sex derived for lower canines were:

$\sigma^{\prime \prime}=-18.406-0.533(\mathrm{RW})+5.550(\mathrm{CT})$

우 $=-11.522-1.118(\mathrm{RW})+5.550(\mathrm{CT})$

\section{- Upper canines of physically matures}

The discriminant analysis classified maximum root width (RW) and upper canine length (UCL) as dimorphic variables (Wilks' Lambda $=0.02377 ; \mathrm{F}(2,10)=205.37$; $p<0.0001)$. The discriminant functions $(n=13)$ were $100 \%$ successful in the classification of sex. The functions of measurements of the crown and root by sex derived for upper canines were:

$\sigma^{\prime \prime}=-817.839+50.808(\mathrm{RW})+18.572(\mathrm{UCL})$

우 $=-384.327+34.434(\mathrm{RW})+12.800(\mathrm{UCL})$ 
Table 2. Student t-test analysis of upper and lower canines (method 2) of A. australis of known sex.

\begin{tabular}{|c|c|c|c|c|c|c|c|c|c|c|c|c|c|c|c|}
\hline \multirow{2}{*}{\multicolumn{3}{|c|}{ CANINES }} & \multicolumn{10}{|c|}{ SEX } & \multirow{3}{*}{$t$} & \multirow{3}{*}{ d.f. } & \multirow{3}{*}{$\mathrm{p}$} \\
\hline & & & \multicolumn{5}{|c|}{ 우 } & \multicolumn{5}{|c|}{0} & & & \\
\hline POSITION & \multicolumn{2}{|c|}{$\begin{array}{l}\text { MEASUREMENT } \\
(\mathrm{mm})\end{array}$} & $\mathrm{n}$ & mean & SD & $\min$ & $\max$ & $\mathrm{n}$ & mean & SD & $\min$ & $\max$ & & & \\
\hline \multirow{12}{*}{$\frac{\grave{d}}{\frac{a}{2}}$} & \multirow{6}{*}{ 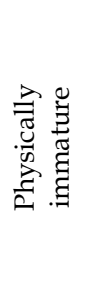 } & $\mathrm{CnL}$ & 25 & 22.40 & 4.85 & 16 & 34 & 67 & 29.54 & 8.03 & 22 & 54 & -4.16 & 90 & 0.0001 \\
\hline & & $\mathrm{CrL}$ & 48 & 13.96 & 2.03 & 11 & 19 & 74 & 17.19 & 1.29 & 13 & 20 & -10.76 & 120 & $<0.0001$ \\
\hline & & $\mathrm{MCrW}$ & 48 & 7.90 & 1.68 & 6 & 13 & 75 & 10.64 & 1.15 & 7 & 13 & -10.77 & 121 & $<0.0001$ \\
\hline & & $\mathrm{CrT}$ & 48 & 6.81 & 1.39 & 5 & 11 & 76 & 9.12 & 0.99 & 6 & 12 & -10.75 & 122 & $<0.0001$ \\
\hline & & MRW & 48 & 8.35 & 1.83 & 6 & 13 & 76 & 11.86 & 1.50 & 8 & 16 & -11.61 & 122 & $<0.0001$ \\
\hline & & $\mathrm{RT}$ & 48 & 6.92 & 1.30 & 5 & 10 & 76 & 9.80 & 1.39 & 6 & 14 & -11.56 & 122 & $<0.0001$ \\
\hline & \multirow{6}{*}{ 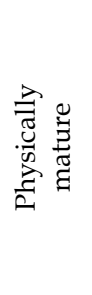 } & $\mathrm{CnL}$ & 4 & 37.00 & 1.83 & 35 & 39 & 9 & 51.56 & 3.47 & 47 & 59 & -7.79 & 11 & $<0.0001$ \\
\hline & & $\mathrm{CrL}$ & 12 & 12.83 & 0.94 & 11 & 14 & 16 & 16.38 & 1.36 & 13 & 18 & -7.73 & 26 & $<0.0001$ \\
\hline & & $\mathrm{MCrW}$ & 12 & 7.58 & 1.44 & 7 & 12 & 16 & 10.79 & 0.85 & 10 & 12 & -7.80 & 29 & $<0.0001$ \\
\hline & & $\mathrm{CrT}$ & 12 & 6.25 & 0.45 & 6 & 7 & 16 & 9.42 & 0.90 & 8 & 11 & -11.27 & 29 & $<0.0001$ \\
\hline & & MRW & 12 & 8.58 & 0.67 & 8 & 10 & 16 & 13.26 & 1.05 & 11 & 15 & -13.78 & 29 & $<0.0001$ \\
\hline & & RT & 12 & 7.58 & 0.67 & 7 & 9 & 16 & 11.53 & 1.43 & 7 & 13 & -8.92 & 29 & $<0.0001$ \\
\hline \multirow{12}{*}{$\begin{array}{l}\dot{0} \\
3 \\
0 \\
\\
\end{array}$} & \multirow{6}{*}{ 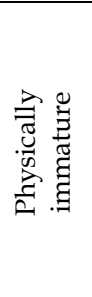 } & $\mathrm{CnL}$ & 4 & 18.75 & 8.02 & 7 & 25 & 20 & 31.90 & 10.69 & 20 & 53 & -2.32 & 22 & $<0.0001$ \\
\hline & & $\mathrm{CrL}$ & 33 & 14.75 & 3.10 & 10 & 21 & 41 & 18.20 & 2.38 & 12 & 22 & -6.34 & 72 & $<0.0001$ \\
\hline & & MCrW & 33 & 7.52 & 1.94 & 6 & 12 & 45 & 10.56 & 1.59 & 6 & 15 & -7.60 & 76 & $<0.0001$ \\
\hline & & CrT & 33 & 5.67 & 1.47 & 4 & 10 & 46 & 7.56 & 1.14 & 4 & 10 & -6.76 & 77 & $<0.0001$ \\
\hline & & MRW & 33 & 8.24 & 2.63 & 6 & 15 & 46 & 12.65 & 2.56 & 7 & 20 & -7.46 & 77 & $<0.0001$ \\
\hline & & $\mathrm{RT}$ & 33 & 5.61 & 1.62 & 4 & 10 & 46 & 8.54 & 4.61 & 4 & 38 & -3.50 & 77 & $<0.0001$ \\
\hline & \multirow{6}{*}{ 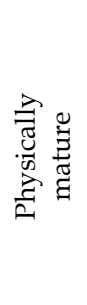 } & $\mathrm{CnL}$ & 0 & - & - & - & - & 2 & 51.50 & 0.71 & 51 & 52 & - & - & - \\
\hline & & $\mathrm{CrL}$ & 7 & 11.71 & 1.38 & 10 & 14 & 4 & 18.50 & 3.00 & 16 & 22 & -5.24 & 9 & 0.0005 \\
\hline & & MCrW & 7 & 6.57 & 0.53 & 6 & 7 & 11 & 11.55 & 1.13 & 10 & 14 & -10.83 & 16 & $<0.0001$ \\
\hline & & CrT & 7 & 5.14 & 0.38 & 5 & 6 & 11 & 8.27 & 0.65 & 7 & 9 & -11.54 & 16 & $<0.0001$ \\
\hline & & MRW & 7 & 8.14 & 0.69 & 7 & 9 & 12 & 15.75 & 2.42 & 10 & 19 & -8.05 & 17 & $<0.0001$ \\
\hline & & RT & 7 & 5.29 & 0.49 & 5 & 6 & 12 & 9.08 & 1.16 & 7 & 11 & -8.14 & 17 & $<0.0001$ \\
\hline
\end{tabular}

$(\mathrm{CnL})$ Canine length, $(\mathrm{CrL})$ crown length, $(\mathrm{MCrW})$ max crown width, $(\mathrm{CrT})$ crown thickness, $(\mathrm{MRW})$ max root width, (RT) root thickness.

\section{- Lower canines of physically matures}

The discriminant analysis classified maximum root width (RW) and maximum width crown (CW) as dimorphic (Wilks' Lambda=0.47708; F(2.28)=15.345; $\mathrm{p}<0.0001)$. The discriminant functions $(\mathrm{n}=31)$ were $83.87 \%$ successful in the classification of sex. Five females were erroneously classified. These functions of measurements of the crown and root by sex derived for lower canines were:

$\sigma^{\prime \prime}=-28.636+0.113(\mathrm{RW})+5.113(\mathrm{CW})$

우 $=-15.951-0.193(\mathrm{RW})+4.103(\mathrm{CW})$

Sex determination using canine teeth of unknown sex individuals and unknown physical development

Discriminant functions obtained by measurements of the crown and root (method 2) (of upper and lower canines) were applied for 51 individuals of unknown sex and unknown physical development. Forty-one and thirty-two upper and lower canines were used respectively. These canines were determined to be from 35 males and 16 females. In eight individuals ( 7 males and 1 female) sex was determined using only lower canine. All the canines were classified correctly using the posteriori classification.

\section{Discussion}

Sexual dimorphism in canine teeth of A. australis was present in physically immature and physically mature individuals. Measurements of the crown and root (method 2) were the most reliable ones for sex determination in upper canines or lower canines, although accuracy rate was higher in upper canines again independent of physical development. 
The selected measurements were different for upper canines (maximum root width and crown length) and lower canines (maximum crown width and root thickness). In canines from individuals of known physical development (physically matures) only one measurements (maximum crown width) was always selected as a dimorphic variable for upper canines $(n=13)$ and lower canines $(n=31)$.

For physically immature individuals the selected variables were the same (maximum crown width and root thickness) for upper and lower canines. However, in physically mature individuals differences were observed in the selected dimorphic variables. These differences could be associated with the size of the canine tooth.

When comparing selected dimorphic measurements of $A$. australis with those selected for $Z$. californianus, the root width and crown length were coincident only for upper canines. Difference in accuracy in the sex determination in the two methods used here could be related to the marked curvature of the canine of $A$. australis, especially in the lower canines. The measurements of the angle of the crown could be useful in teeth where the crown of the canine is straight, such as those of O. flavescens.

As also described in other pinnipeds species, the sexual dimorphism in the canines of A. australis is accentuated with growth of the animal. However, in physically immature individuals (less than 1 year old) visual examination is not easy or even possible.

The above results could be useful as another tool in determining sex estimation of osteological material accessed in scientific collections and/or museums, and with some caution in physically immature specimens. Application of this methodology in A. australis canine teeth is a fast and economical method and its application will allow an increase in sample sizes in future studies of population dynamics, individual and geographical variation and taxonomic comparisons.

\section{Acknowledgements}

Thanks to all those involved in fieldwork in Rio Grande. This study was part of a Master Thesis by D. MolinaSchiller, which was supported by grants from CNPq (136348/96-3) and FAPERGS (96/60143.7). We thank Dr. Miriam Marmontel, Dr. Oliver Boisseau and an anonymous referee for reviewing the English and for their helpful comments on the manuscript.

\section{References}

Brunner, S. (2002) Geographic variation in skull morphology of adult Steller sea lions (Eumetopias jubatus). Marine Mammal Science, 18(1): 206-222.

Crespo, E.A. (1984) Dimorfismo sexual en los dientes caninos y en los cráneos del lobo marino del sur, Otaria flavescens (Shaw) (Pinnipedia, Otariidae). Revista del Museo Argentino de Ciencias Naturales "Bernardino Rivadavia", Zoología. 13(25): 245-257.

King, J.E. (1983) Seals of the World. British Museum (Natural History) and Cornell University Press, 240pp.

Laws, R.M. (1993). Antarctic Seals. Research Method and Techniques. Cambridge University Press. 390pp.

Le Boeuf, B.J.E.R. and Laws, M. (1994) Elephant seals. University of California Press, Berkeley, CA. 414pp.

Lowry, M.S. and Folk R.L. (1990) Sex determination of the California sea lion (Zalophus californianus) from canine teeth. Marine Mammal Science 6(1): 25-31.

Molina-Schiller, D.M. (2000) Age and cranial development of the South American fur seal, Arctocephalus australis (Zimmermann, 1783) (Carnivora: Otariidae) in the coast of Rio Grande do Sul, Brazil. Master Thesis. Fundação Universidade Federal do Rio Grande (FURG). Rio Grande, RS, Brazil. 117pp.

Ridgway, S.H. and Harrison, R.J. (Eds) (1981) Handbook of Marine Mammals: The Walrus, Sea Lions, Fur Seals and Sea Otter. Volume 1. Academic Press, London.

Riedman, M. (1990) The Pinnipeds. Seals, sea lions, and walruses. University of California Press. 439pp.

Scheffer, V.B. (1958) Seals, sea lions, and walruses. A review of the Pinnipedia. Stanford. CA. Stanford University Press. 179pp.

Zar, J.H. (1984) Biostatistical Analysis. Prentice-Hall Inc. New Jersey, EUA. 718pp. 